\title{
'Reflection is embedded in my brain forever now!': personal development as a core module on an Executive MBA
}

Article

Accepted Version

Dalton, C. (2018) 'Reflection is embedded in my brain forever now!': personal development as a core module on an Executive MBA. Reflective Practice, 19 (3). pp. 399-411. ISSN 1470-1103 doi:

https://doi.org/10.1080/14623943.2018.1479690 Available at https://centaur.reading.ac.uk/78697/

It is advisable to refer to the publisher's version if you intend to cite from the work. See Guidance on citing.

To link to this article DOI: http://dx.doi.org/10.1080/14623943.2018.1479690

Publisher: Informa UK Limited

All outputs in CentAUR are protected by Intellectual Property Rights law, including copyright law. Copyright and IPR is retained by the creators or other copyright holders. Terms and conditions for use of this material are defined in the End User Agreement.

www.reading.ac.uk/centaur 
Central Archive at the University of Reading

Reading's research outputs online 


\section{"Reflection is embedded in my brain forever now!": Personal Development as a core module on an Executive MBA}

\section{Dr Chris Dalton}

Henley Business School, University of Reading

Greenlands, Henley-on-Thames, Oxfordshire

RG9 3AU

Chris.dalton@henely.ac.uk

\section{Word count: 6,240}

\section{Acknowledgement: $\quad$ I would like to thank Professor Jane McKenzie at} Henley Business School for her frequent and seeringly perceptive comments on drafts of this paper.

\section{Notes on the contributor Chris Dalton is Associate Professor of Management}

Learning and subject leader for Personal Development at Henley Business School, University of Reading. His research interests include the nature and use of reflection in post-experience management education, and the use of systemic constellations in organisational development. Chris holds a $\mathrm{PhD}$ in Management Learning from Lancaster University, and an MBA from Henley. His first book, The Every Day MBA, was published at the beginning of 2015 and his second, Brilliant Strategy for Business, was released in 2016. 
"Reflection is embedded in my brain forever now!": Personal Development as a core module on

\begin{abstract}
Professional progression and skills development are the main expectations of mid-career managers when enrolling on an Executive MBA (EMBA), yet it can be personal development (PD) that turns out to be the unexpected benefit of management education. Joining a growing number of voices making a case for personal development and selfawareness in management education, and calling for schools to incorporate it in the curriculum, this paper advances the case for personal development as a core Executive MBA module. The paper sets out the holistic rationale and philosophic principles used to design and deliver a course underpinned by curiosity and self-reflection on an EMBA in the United Kingdom, and presents empirical findings from a survey conducted among 230 students and alumni. These suggest that the focus on reflective practice and integration of PD promotes a richer and deeper appreciation of the value of reflection for lasting and sometimes unexpected personal growth. In addition, the raising of awareness of self also brings awareness of others, and develops critical thinking in application of the MBA at work. The paper concludes with a discussion re-evaluating the subject of tacit knowledge in reflective practice.
\end{abstract}

\title{
Key words
}

Personal development, reflection, reflective practice, Executive MBA, management education 
"Reflection is embedded in my brain forever now!": Personal Development as a core module on

\section{Introduction}

This aim of paper is to join ongoing discussion around philosophic principles in management education (Schwandt 2005), by focusing on the nature and use of reflection (Wagenheim 2014, Hébert 2015) on an Executive MBA (De Dea Roglio \& Light 2009, Albert \& Grzeda 2014). The Executive MBA (EMBA) is a variant of the ubiquitous business degree aimed at in-work and experienced managers that has grown in global popularity in recent decades. Ideally, an EMBA exemplifies how post-experience management education offers business leaders a link between thought and action in service of personal, economic and social ends. Managers expect this education to effect professional change by aligning their own experiential know-how with a business school's academic know-what, which in measurable terms should relate to greater competency in organisational and transformational leadership. At the same time, and at the cusp of the Anthropocene epoch (Slaughter 2012) in which human activity is said to have direct and irreversible effects on the ecosystem, the practitioner must remain open to revisiting and reflecting on their personal basis of sense and meaning making. Research relevant to this aspect of management education has looked at individual learning through diverse lenses such as identity discourse (Alvesson et al, 2008), competence building and behaviour change (Rubin \& Dierdorff 2009), emotional intelligence and growth (Boyatzis et al 2013), as well as self-knowledge and reflection (Reynolds 1998, De Dea Roglio \& Light 2009, Petriglieri et al 2011, Andersson 2012). Dogged by persistent criticism as to their efficacy and relevance over the years (Porter \& McKibbin 1988, Leavitt 1989; Adler 2002; Pfeffer and Fong 2002; Weick et al. 2005; Raelin 2007), Executive MBA programs have been influenced by theoretical input from faculty via research and teaching (Donaldson 2002, Ghoshal 2005) and market 
"Reflection is embedded in my brain forever now!": Personal Development as a core module on

consideration of the graduate skills or attributes needed for future employability (Rubin \& Dierdorff 2009, 2013). In management education personal development is shaped by students' encounters with it in the institutional setting. Participants can (sometimes unexpectedly) encounter profound, existential awakening and re-organisation of the self during their studies yet relatively few business schools facilitate this. This paper describes the context and philosophical presuppositions, and the design and delivery of a PD course for mid-career managers. It presents survey evidence from alumni of the impact of module, and discusses some implications for reflection and reflective practice as a result.

\section{Personal development on the Executive MBA}

Managers have societal power and influence; what they decide, what they devise, and what their companies do, create ripples that are economic, societal and environmental (Anderson 2011). Myriad technological, social and economic changes have shaped the world's developed and developing economies, creating new industries and shifting patterns of work (Okhuysen et al 2015). Mid-career managers enrol on an Executive MBA for multiple reasons and with objectives connected with the authority of their positions (Reeves \& Rimmer 2007). Aside from improving technical expertise in a current role and deepening general business vocabulary, the EMBA is said to deliver a boost to self-confidence when dealing with other business functions (Sturdy et al 2006, Cruz and Wood 2015). Further, the degree's focus on leadership, peer-to-peer networking and career advancement all impact on the person. But should it aim for more? As mid-life and mid-career are periods of transition and development (Erikson 1994, Sugarman 2001, Ibarra 2003), the motivation toward self-discovery is also a 
"Reflection is embedded in my brain forever now!": Personal Development as a core module on

fundamental (if obscure) aspect of an adult's return to school. Without a framework to make sense of it, any disequilibrium experienced might either be ignored or compensated for, and the whole opportunity (dis)missed. This is nontrivial. Managers can train for skills and behaviors to navigate their way through business problems (Hogan and Warrenfeltz 2003) but to transcend the functional siloes and master the wider purpose of management, self-awareness is key. At the heart of management education is often a search for wisdom in managerial judgement. There have been calls for this in the literature, for example through the lens of phronesis, or the ability to read new situations and apply - intuitively, imaginatively and spontaneously - one's practical wisdom. Shotter and Tsoukas (2014), for example, explore the fuzzier, unspecifiable part of managerial judgement when a manager comes across a felt difficulty.

Personal Development Planning is defined by the United Kingdom's QAA (Quality Assurance Agency) as:

"a structured and supported process undertaken by a learner to reflect upon their own learning, performance and/or achievement and to plan for their personal, educational and career development" (QAA 2009) (p. 2, emphasis added).

This contains a principle of self-direction but it is important to note provision of scaffolding and facilitation, too. Scaffolding, or the ongoing and calibrated provision of support of learning and development (Puntambekar \& Hubscher 2005), appropriately holding and releasing control in context, suggests that PD won't just happen by itself. Though management educators seem generally in favour of personal development and reflective practice, prescription has been more difficult to achieve (Yanow \& Tsoukas 2009). 
"Reflection is embedded in my brain forever now!": Personal Development as a core module on

At the heart of the QAA statement is reflection, reference to which is uncontroversial in adult education and learning. Reflection is asserted as useful on the premise that it performs and explains discovery and development of thinking skills relevant to professional practice (Scanlon \& Chernomas 1997). Schön's summary of how professionals use thinking in action (1983) has fathered the codification of reflection into process models containing sequential phases (e.g. Boyd \& Fayles 1983, Atkins \& Murphy 1993, Jay \& Johnson 2002). In managerial training - if it features at all reflection comes usually in the guise of post-hoc process or skill, explicit and mastered through careful application as a purposeful and systematic means of concentrating (perhaps at a later time) on details of an event or a matter of concern triggered by an issue which is out of the ordinary. But how true to reality are frameworks and models? Managers can struggle meaningfully to fit indistinctly-shaped pegs of experience into the very square holes of models of the learning process. At the same time, as Boud et al note, 'experience alone is not the key to learning' (1994 p. 7). What else is needed? Perhaps it is development of one's perception of the nature of experience that is more crucial to learning from change.

\section{The philosophical basis for reflective practice on the Executive MBA}

In 2006 a personal development module was introduced as a credit-bearing and mandatory module on an Executive MBA at business school in the United Kingdom. The MBA has over 2,500 enrolled members studying in two

UK campuses and eight satellite locations worldwide. Students are aged on average 38 at start and nearly all are in full-time employment throughout. In 2010 the PD module was revised with a more systemic outlook, in line with holistic principles (Shefy \& Sadler- 
"Reflection is embedded in my brain forever now!": Personal Development as a core module on

Smith 2006, Gerstner 2011,Yang \& Goralski 2016). These changes were mainly influenced by Gregory Bateson's (1979) work on epistemology, and greater emphasis was placed on co-exploration of the nature of reflection and self-awareness than on the prior focus on competency-building and planning portfolios. To this end, and in service of Waddock and Lozano's (2013) call for a holistic approach to management education as "reflective, practice-based, self-aware learning" (p. 283), the PD module brings students' awareness to the recurring motif of disequilibrium. Disequilibrium is a feature of a great many ideas of learning and change. For example, both Dewey's educative learning from problematic experiences and the first stage for Schön's reflective practitioner (1983) feature imbalance or dilemma. But rather than seek closure by completing some kind of learning cycle, the PD module encourages open enquiry into the premises of disequilibrium ${ }^{1}$. It is easy to begin to peel back the outer layers of one's assumptions, but it can be more difficult to examine paradigmatic (and pre-conceived) ideas of how the world is. The working definition of personal development applied at is:

the identification and removal of those restraints that limit the likelihood of sustainable individual, organizational, social and environmental health and well-being.

To facilitate reflective practice, the tutor must be in service of the identification and not the removal of restraints, which must be the task of the student. In moving from

\footnotetext{
${ }^{1}$ Holding off closure is a challenge for task-focused executives who have just paid a lot of money!
} 
"Reflection is embedded in my brain forever now!": Personal Development as a core module on

experience through reflection to awareness, the module uses several presuppositional statements ${ }^{2}$ drawn from three spheres of philosophical consideration:

1. Ontological: that the nature of reality is an undifferentiated and unpunctuated flow of events with no inherent boundaries. Reality is of-itself so.

This is a realist position; i.e. there is a universe 'out there' that is real, and it is what it is regardless of our knowing or not knowing about it. We are constituent of reality, but our understanding of what reality is must, necessarily, only ever be partial because we are incapable of standing outside the unpunctuated flow of events without in some way performing an act of division, cut or punctuation. This rather implicit presupposition is made explicit in the final PD workshop as surfacing assumptions at this most basic level models the path to awareness of what thinking is, from which we form judgements that in turn are the basis of management and practice.

2. Epistemological: that knowledge is punctuation of the unpunctuated. The most basic form of punctuation is differentiation but most managers are not conscious of how they think.

As a social species, human self-interest has evolved in ways to experience life as a set of communicative processes. Since knowledge (punctuation) of reality is socially constructed and mediated, our systems of punctuation (knowledge) may be useful but ultimately are all arbitrary (Bateson 1979). Over the last 200 years effective management

\footnotetext{
${ }^{2}$ A statement in response to a question is a proposition. A statement that gives rise to a question is a presupposition. Presuppositions can also be illustrative of abductive inference in reflection.
} 
"Reflection is embedded in my brain forever now!": Personal Development as a core module on

has been predicated on the ability of managers to draw useful distinctions and boundaries, frame problems in order to solve them, and find better ways of understanding the world around to organise the activities of others. Nearly all this sensemaking goes on as taken-for-granted. The starting point for personal development, as for all learning and development, is awareness ${ }^{3}$ of the context-dependent punctuation of the flow of events into experience. In personal development, the root metaphor for awareness is the self (Bateson \& Bateson 1988).

Any stimulus which goes unnoticed (for humans the vast majority of sensory input and, by definition, all unconscious data surely falls into this category) has traditionally remained outside the potential for reflection and reflective practice. This presupposition permits the educator to draw attention, in contexts accessible for mid-career managers, to the nature of disequilibrium. Without this, the manager cannot begin to interrogate the assumptions behind all sense-making up to that point. Tipping points, conflicts, paradoxes, dilemmas and thresholds are all desirable in the formal learning environment to provoke disequilibrium. Knowing that one is being taken to the edge of knowing/notknowing becomes the field of enquiry.

3. Axiological: that managerial judgement about a course of action is derived from three things, Practice (the sum of what is known from experience),

\footnotetext{
${ }^{3}$ Awareness is an open and intelligent mind-set that looks without judgement at how meaning is inherent in our punctuation of events.
} 
"Reflection is embedded in my brain forever now!": Personal Development as a core module on

Principles (the sum of what is known about theory) and Stance (the sum of what is known about the self).

Stance is a term borrowed from systemic coaching and constellations (Whittington 2013) and means, among other things, paying attention to mind-set, attitudes, values, beliefs. It also represents the orientation of the manager in the business system. Stance is the selfawareness through which management principles are evaluated and applied to practice. The plethora of management concepts, frameworks, models and theories on an MBA address axiological questions such as 'what needs to be done?' and 'what is the right thing to do?' Without reflection on Stance, a manager's risks being unreflexive and mechanistic. Therefore, Stance is the most crucial aspect to develop awareness of.

Grey (2002) argues that management education should purposively orient managers toward certain values so that it "develops the "skill" of appropriate selfhood - a technique of self-construction and identity and value formation' (Grey 2002 p. 500) and this might suggest that reflection should inhabit notions of power, control or domination (Ford et al 2010). This feels too full judgmental, so the EMBA PD module looks beyond axiological posturing to epistemic assumptions (Hühn 2014). Reflection is equated to an individual acknowledging without judgement the world as it is.

\section{The Personal Development module and survey}

The PD module appears on day one of the programme and consists of four one-day workshops, three tutor-marked (but not graded) reflective assignments, and dedicated study guide and materials. Workshops are an opportunity for course members to experience reflective responses to two sets of triggers, the first of which embraces 
"Reflection is embedded in my brain forever now!": Personal Development as a core module on

relationships with fellow learners, as well as application of the MBA curriculum to practice and career development. These elements, of course, may be part of every MBA experience, but the second set of triggers are less common. Here, the tutor respectfully facilitates enquiry into epistemology, or the nature of the reflective process itself. The method is to impede ${ }^{4}$ that which has been habituated or taken-for-granted in selfawareness. Finding imbalance or disequilibrium is an epistemic excuse to investigate managerial grounds for sense-making more widely (the aim is for managers to have more choice, but without having this imposed on them in terms of models and framweorks). In this way they may gain a deeper understanding of what restricts them in their development.

The module has been in part of the course in its current format for about seven years, but has collected only sporadic and unsolicited feedback from course members during that time. In November 2016 an invitation was circulated to around 9,000 alumni and current students to take part in an online survey, with predominantly open-ended questions. 230 people responded, of which $80 \%(\mathrm{n}=186)$ had taken the PD module as part of their course. The remainder $(n=38)$ had graduated from before it was introduced, or had not completed their studies $(n=8)$. Alumni $(n=113)$ and current students $(n=73)$

\footnotetext{
${ }^{4}$ This is analagous to the way that people walking in a busy street unconcsciously find agreement with those coming in the opposite direction not to bump into each other. Movements coordinate with paths of others, but from time to time, this unspoken pattern is broken and people find themselves, without intent, apologetically nose to nose with a stranger, who momentarily has also been stopped in their tracks. The tutor is, in effect, deliberately placing themselves in the mental path of the student in the PD workshop. The aim is to throw the other slightly out of their routine.
} 
"Reflection is embedded in my brain forever now!": Personal Development as a core module on

graduating post-2008 (with the PD module) were asked questions about their definition of PD, starting expectations, changes in viewpoint, content, stand-out or 'ah-ha' moments, and impact of PD on them personally. For the others $(n=38)$, questions about PD module impact and content were omitted. Some contrast between the two otherwise homogenous groups was therefore possible. Data was analysed using themes derived using an interpretative approach, bearing in mind the caveat in van Manen's (1990) advice that although "theme is the means to get at a notion" (p. 88), it is inevitably a reduction of the notion being expressed. The survey produced two findings pertinent to the aim of this paper:

\section{Finding 1: Executive MBAs define Personal Development more fully when required to engage with it.}

This may seem obvious. After all everything tends to be more well-defined when closely examined, but many top business schools claim personal growth for their MBAs without supplying a module to promote it. The richness in insight reported by respondents who had taken the PD module indicated that reflective practice produces a qualitative difference in student outcomes. The survey began by eliciting definitions of personal development. Five themes emerged from the comments, ranging from the practical to the transcendent:

1. Tools and techniques for working on strengths and weaknesses;

2. Filling gaps in development, behaviours, skills or competences;

3. Active search for ongoing personal growth, goals, planning or self-improvement or direction; 
"Reflection is embedded in my brain forever now!": Personal Development as a core module on

4. Personal insights, self-awareness, reflection and responsibility for sense-making.

5. Finding holistic purpose or balance, concern for one's impact on others and society.

Pre-2010 students tended to write rather brief responses, with little narrative. Selfreflection was rarely referenced and the dominant theme was to see personal development as a gap-fill for knowledge, skills or competences, mainly through the application of MBA theory at work. Typical of this were the following:

'I believe it is how to use the things you have learned into your own setting.'

'Personal development is about the improvement of a person, through skills enhancements, increasing the awareness of the person about his/her capabilities.'

For this group the MBA (and by extension personal development) provided a toolkit. There was evidence of continual and incremental improvements of managerial effectiveness, not transformation. In contrast, those who had taken the PD module made frequent reference to defining core assumptions, understanding holistic theories of reflection and self-awareness, and the role that such things have in a forming a nuanced view of learning. For some, the message of the module continued maturing even after graduation. As one alumnus memorably put it:

'Reflection is embedded in my brain forever now!'

In fact, nearly two-thirds of responses about the definition of PD alluded to selfresponsibility and self-awareness (themes three and four): 
"Reflection is embedded in my brain forever now!": Personal Development as a core module on

'Personal development is the term used to describe the process we use to better understand the transformational journey we go on throughout the MBA and our lives in general. At ___ ${ }^{5}$ it's about opening our eyes and making that a conscious process through reflection, critical analysis and feedback.'

Another respondent described the application of reflection to the locus of control and direction in their career:

'The ability to steer yourself through your professional life using insight gained through self-awareness and reflection. A preference for making pro-active choices for quantifiable reasons rather than allowing your professional life to be something that happens to you.'

As with the non PD students, alumni indicated satisfaction from the career progression offered by their MBA, but with an extra dimension:

'Self-reflection to identify where I am currently (A) and where I am aiming to get to (B). I see it as a gap analysis followed by planning and taking concrete actions to get from A to B. It is iterative, in terms of re-assessing both A and B, and in assessing the effectiveness of the actions taken in moving from A to B. The activity takes place across a number of dimensions (e.g. technical, academic, personal, social) and across a number of timeframes (e.g. 2, 5, 10, 30 years) such that achieving consistency/clarity of thought across all dimensions

\footnotetext{
${ }^{5}$ The name of the business school has been removed to maintain anonymity in peer-review
} 
"Reflection is embedded in my brain forever now!": Personal Development as a core module on

and timeframes is in itself an achievement! Self-awareness is both a prerequisite to successful personal development and a hurdle, insofar as meaningful self-awareness is very hard to achieve.'

All respondents were given the chance to add their reactions to a draft report of results, and one alumnus whose MBA did not have a PD module wrote:

'I can well relate to your distinction of responses between the two groups (i.e. pre and post 2008) as mine were very brief and characterised as you suggest. I would certainly have gained from the PD module. I always refer to my 'toolbox' and ability to adopt an appropriate / contingent approach to a particular situation post the MBA, whereas pre the MBA I was a one-trick pony, one (finance trained / focused) solution fitted all! However, I never refer to the confidence that the MBA gave me to interact with other managers on any topic from a more level playing field and I shall do so ongoing now.'

It is encouraging to find that the presence of a PD module on the Executive MBA can initiate a deeper exploration of motivations and expectations, and an opportunity to challenge and reflect more fully on deeply-held assumptions. But it is another question as to whether this difference makes any difference. The second relevant finding from the survey was that, yes, it does.

Finding 2: $\quad$ Reflection brings levels of self-awareness and contributes to better outcomes on the EMBA. 
"Reflection is embedded in my brain forever now!": Personal Development as a core module on

Self-reflection changes perspectives (as $82 \%$ of those who had PD agreed indicated), but it was found that the PD module often had more than one kind of impact. Survey responses to the question what had changed produced five themes, from the transactional to the transformational:

1. Integration of learning in other subjects on the MBA;

2. Improvement in skills and performance as a manager or leader;

3. Notice of a gradual change to a more reflective outlook and attitude;

4. Discovery of a process to go deeper and deeper, to find an (unexpected) connection with self;

5. Road to Damascus! From sceptic to convert, and advocate. The penny having dropped, now believing PD to be the most important subject on the MBA.

Themes two, three and four accounted for the majority of comments, indicating that the luxury of time and space to think, and permission to surface assumptions were catalysts for a deeper shift in attitude rippling into other parts of life:

'In the beginning my personal development was mostly about me, of course. Later on by digging deeper - not at least through the extracurricular PD sessions things became more clear. My view has changed completely and my view even on human beings in general have changed to look more for the relation between them than at the individual including myself.'

Specifically, some respondents found that the PD contributed value by allowing them to put other management subject areas into perspective. One person reported how: 
"Reflection is embedded in my brain forever now!": Personal Development as a core module on

'I've recognised throughout the MBA journal and more strongly post the formal learning theatre, the subjects studied are all in essence addressing areas of weakness in knowledge. The PD program provided me a stronger ability to seek these areas out for myself and strength them either with supporting further learning or recruiting others to address my weaker areas.'

The scope and depth of the impact of a deliberately open and reflective personal development course went unexpectedly beyond the increased in skills and selfconfidence reported by alumni graduating before PD was introduced. For one person:

'The personal development module was the unexpected treasure within the MBA and something which differentiates, say, an MBA from any other master's level course. The impact is principally self-awareness and self-confidence. As a consequence, I've acquired the ability to forgive myself for not being perfect at every aspect of management.'

Others found their career direction and plans interrupted:

'The module had me thinking that life is not just about climbing up the corporate ladder. But to stop at some point, allow the wind to take its own course and breathe a new air.'

Many reported an awakening during the course, as the following example illustrates:

'At about the mid-point in the MBA I started to understand the key underlying reason that I was taking an MBA. The PD module was an essential part of this process, but I really had not expected this. To be honest I had not really 
"Reflection is embedded in my brain forever now!": Personal Development as a core module on

considered PD as a key part of the MBA. I had already taken a business degree and several professional qualifications and so I had just been expecting to learn more business theory and techniques. I had not expected to be challenged on my motivation for taking an MBA.'

Arguably the most significant finding was frequent mention of the importance and value of reflection:

\footnotetext{
'Through progression of the programme, I have grown to question myself, my values and surroundings, reflection is such a strong tool in a fix it now environment.'
}

'Conscious self-reflection was not part of my "portfolio", it is now.'

When survey participants were asked to rate how important for career success were each of the three aspects of management (Practice, Principles and Stance) it was Stance that was consistently seen as the most important.

\section{Discussion: reflections on the tacit in reflective practice}

An Executive MBA, a major investment of time and money, is also the juggling of socially-mediated roles at a pivotal time in an adult's life. In that sense, perhaps it is a search for a coherent and ethical role as a manager that is the personal development aspect of the EMBA. The search in adult education for ways to codify the potential for personal development is not new. John Dewey's (1933) definition of reflection has been the starting point for many. Rooted in scientific inquiry and informed by a philosophical purpose for education as fundamental to democracy, it sees it as: 
"Reflection is embedded in my brain forever now!": Personal Development as a core module on

'the active, persistent and careful consideration of any belief or supposed form of knowledge in the light of the grounds that support it and the further conclusions to which it tends' (1933 p. 7).

Dewey held that reflection is generated by encounters with the potential inherent in experience; but only if the person is open-minded to the possibility of such meanings. The emphasis there is on questioning beliefs, but as the potential inherent in experience is also a matter of how you think, an awareness of what constitutes your epistemology must be pre-requisite. A non-judgmental curiosity is required in adult learning and change, particularly as the nature of this encounter is one of disequilibrium, or perplexity, caused by a situation which runs counter to the individual's balance. On an Executive MBA the surprise is often how reflection reveals a multi-faceted and selfguided liminal narrative, of being "betwixt and between social roles and/or identities" (Ibarra \& Obodaru 2016). In this sense, prior experience can both enable and limit the learner's own ability to develop. To hold the space for reflection, curiosity and selfawareness to flourish is a delicate question for many academics, who can be just as unself-aware as anybody else. The temptation to retreat to a model or framework in the face of the messy complexity of events is therefore not surprising. It is, however, misplaced. Reflective practitioners must see beyond what have become rather fixed and mechanical representations of change. For example, Experiential Learning Theory (Kolb 1976; Kolb \& Kolb 2005), based in large part on Lewin's and Dewey's approaches, has regarded reflection as a cognitive step in a sequence of learning that can be modelled and categorized for managers (Mumford 1995; Meyer 2003). Donald Schön's Reflective Practitioner, positioned as counterpoint to technical-rationality, requires the professional to premise progress quite deductively in the scientific method. 
"Reflection is embedded in my brain forever now!": Personal Development as a core module on

The usefulness of reflection in personal development, however, derives more from the conscious relocation of transformation closer and closer to the in situ of the present, and not through studious application of further elements of punctuation of process. This makes PD fundamentally about awareness-building in liminal contexts where there is no unmediated route to underlying, or tacit, reality. In this respect it comes up against a popular and pervasive interpretation of Michael Polanyi's tacit knowing (1966) as knowledge conversion (Nonaka 1994) that is often used in modelling reflective practice. Tsoukas (2011) points out that Polanyi had a more fundamental epistemic aim and was drawing our attention to a theory of mind and nature in which tacit means the inaccessible structure underlying all knowing. This anthropocentric boundary zone in knowing (Waters et al 2014) is tantalisingly difficult to pin down but as a Polanyi contemporary, Gregory Bateson, put it:

'The point of the probe is in the heart of the explorer: what is $m y$ answer to the question of the nature of knowing? I surrender to the belief that my knowing is a small part of a wider integrated knowing that knits the entire biosphere or creation.' (1979, p. 93, emphasis in the original)

Personal development necessarily involves that which is beyond our consciousness selves, so a less rigid and more playful 'surrender to systemic truths', as understood in this paper by Stance, can bring managers closer to Polanyi's original view of the tacit. This does not require wholescale rejection of past theories of reflection but rather a shift in emphasis in line with questioning the complex and reflexive role of the manager. At present, many management practices are predicated on an expectation of the manager as "the one in charge"; controlling, overcoming and subduing the world for profit or 
"Reflection is embedded in my brain forever now!": Personal Development as a core module on an Executive MBA

progress. If the Executive MBA should equip managers to act wisely and humbly in organisational settings, it must start by helping them understand themselves. The aim of this paper was to introduce a definition of personal development that is balanced and holistic, and say something on the design and delivery of a reflective PD module. The empirical evidence offers a glimpse of an evolving understanding of the subject and more work needs to be done to evaluate ways of interrupting managers' established or taken-for-granted patterns of thinking in order to facilitate greater personal freedom and purpose for them as adults, and to exercise choice and wisdom in sustainable, responsible value creation at work. 


\section{References}

Adler, P. S. (2002). Corporate scandals: It's time for reflection in business schools. Academy of Management Executive 16(3): 148 - 149.

Albert, S., Grzeda, M. (2014). Reflection in Strategic Management Education, Journal of Management Education Vol 39, Issue 5, pp. 650 - 669

Alvesson M, Ashcraft, K. L., Thomas, R., (2008). Identity Matters: reflections on the construction of identity scholarship in organizational studies, Organization, 15 (1), 5-28

Anderson, R. (2011). Confessions of a Radical Industrialist: How Interface proved that you can build a successful business without destroying the planet, Random House Business

Andersson T. (2012). Normative identity processes in managers' personal development training, Personnel Review, 41 (5), 572-589

Atkins, S. and Murphy, K. (1993). Reflection: a review of the literature. Journal of Advanced Nursing 18: 1188-1192.

Bateson, G. (1979). Mind and Nature: a necessary Unity. London, Wildwood House.

Bateson, G. and M. C. Bateson (1988). Angels Fear: Towards an Epistemology of the Sacred, Bantam Books.

Boud, D., Keogh, R., Walker, D. (1994). Reflection: Turning Experience into Learning, Routledge Falmer

Boyatzis, R, Smith, M, Van Oosten, E, \& Woolford, L (2013). Developing resonant leaders through emotional intelligence, vision and coaching, Organizational Dynamics, 42, pp. 17-24,

Boyd, E. M. and Fayles, A. W. (1983). Reflective Learning: key to learning from experience, Journal of Humanistic Psychology 23(2): 99-117.

Cruz, J. Wood T. (2015). Perceived effects of part-time MBAs on careers, Career Development International, Vol. 20 Iss: 6, pp.646 - 662

De Dea Roglio, K. and G. Light (2009). Executive MBA Programs: The Development of the Reflective Executive. Academy of Management Learning \& Education 8(2): $156-173$. 
"Reflection is embedded in my brain forever now!": Personal Development as a core module on

Dewey, J. (1933). How We Think. A restatement of the relation of reflective thinking to the educative process (Revised edn.). Boston, D. C. Heath.

Donaldson, L., (2002). Damned by Our Own Theories: Contradictions Between Theories and Management Education, Academy of Management Learning \& Education, 1: 1, pp 96-106

Erikson, E. H. (1994). Identity and the life cycle, W W Norton.

Ford, J, Harding, N, \& Learmonth, M (2010). Who is it That Would Make Business Schools More Critical? Critical Reflections on Critical Management Studies', British Journal Of Management, 21, pp. 71-81

Gerstner, Q. (2011). Leadership and organizational patterns in the Daodejing, Journal of Management Development, Vol. 30 Issue: 7/8, pp.675-684

Grey, C. (2002). What are Business Schools for? On silence and voice in management education. Journal of Management Education 26(5): 496-511.

Ghoshal, S. (2005) Bad Management Theories Are Destroying Good Management Practices, Academy Of Management Learning \& Education, (1), 75

Hébert, C, (2015) Knowing and/or experiencing: a critical examination of the reflective models of John Dewey and Donald Schön, Reflective Practice, 16:3, 361-371

Hogan, R, \& Warrenfeltz, R (2003). Educating the Modern Manager, Academy Of Management Learning \& Education, 2, 1, pp. 74-84

Hühn, M., (2014). You Reap What You Sow: How MBA Programs Undermine Ethics, Journal Of Business Ethics, 121, 4, pp. 527-541

Ibarra, H. (2003). Working Identity: Unconventional Strategies for Reinventing Your Career. Harvard Business School Press.

Ibarra, H, \& Obodaru, O. (2016). Review: Betwixt and between identities: Liminal experience in contemporary careers, Research In Organizational Behavior, 36, pp. 47-64

Jay, J. K. and K. L. Johnson (2002). Capturing Complexity: a typology of reflective practice for teacher eduaction. Teaching and Teacher Education 18: 73-85.

Kolb, A. Y. and D. A. Kolb (2005). Learning Styles and Learning Spaces: Enhancing Experiential Learning in Higher Education. Academy of Management Learning \& Education 4(2): 193-212. 
"Reflection is embedded in my brain forever now!": Personal Development as a core module on

Kolb, D. A. (1976). Management and the Learning Process. California Management Review XVIII(No. 3): 21-31.

Leavitt, H. J. (1989). Educating Our MBAs: On Teaching What We Haven't Taught. California Management Review 31(3): 38-50.

Meyer, J. P. (2003). Four Territories of Experience: A Developmental Action Inquiry Approach to Outdoor-Adventure Experiential Learning. Academy of Management

Mumford, A. (1995). Four Approaches to learning from experience. Industrial \& Commercial Training 27(8): 12-19.

Nonaka, I., (1994). A Dynamic Theory of Organizational Knowledge Creation, Organization Science, 5:1, pp 14 - 37

Okhuysen, G., Lepak, D., Lee Ashcraft, K., Labianca, G., Smith, V., Steensma H (2015). Theories of Work and Working Today, Academy Of Management Review, 4015, pp. 6-17

Petriglieri, G, Wood, J, \& Petriglieri, J. (2011). Up Close and Personal: Building Foundations for Leaders' Development Through the Personalization of Management Learning, Academy Of Management Learning \& Education, 10, 3 , pp. $430-450$

Pfeffer, J. and C. T. Fong (2002). The End of Business Schools? Less Success Than Meets the Eye. Academy of Management Learning \& Education 1(1): 78-95.

Polanyi, M., (1966). The Tacit Dimension. New York, Doubleday.

Porter, L. W., \& McKibbin, L. E. (1988). Management education and development: Drift or thrust into the 21st century? New York: McGraw-Hill.

Puntambekar, S, \& Hubscher, R (2005), Tools for scaffolding students in a complex learning environment: What have we gained and what have we missed?, Educational Psychologist, 40, 1, pp. 1-12

QAA (2009). Personal Development Planning: Guidance for institutional policy and practice in Higher Education. Quality Assurance Agency 2009

Raelin, J. A. (2007). Toward an Epistemology of Practice. Academy of Management Learning \& Education 6(4): 495-519.

Reeves, Q., Rimmer, R. (2009). Explaining performance in an Executive MBA, International Journal of Management Education, 7 (1) 
"Reflection is embedded in my brain forever now!": Personal Development as a core module on

Reynolds, M. (1998). Reflection and Critical Reflection in Management Learning. Management Learning 29(2): 183-290.

Rubin, R, Dierdorff, E. (2009). How Relevant Is the MBA? Assessing the Alignment of Required Curricula and Required Managerial Competencies, Academy Of Management Learning \& Education, 8, 2, p. 208-224

Rubin, R, Dierdorff, E. (2013). Building a Better MBA: From a Decade of Critique Toward a Decennium of Creation, Academy Of Management Learning \& Education, 12:1, p. 125-141

Scanlon, J. and W. Chernomas (1997). Developing the reflective teacher. Journal of Advanced Nursing 25: 1138-1143.

Schön, D. A. (1983). The reflective practitioner: how professionals think in action. San Franscisco, Jossey-Bass.

Schwandt, D. R. (2005). When Managers Become Philosophers: Integrating Learning with Sensemaking. Academy of Management Learning \& Education 4(2): 176192.

Shefy, E., Sadler-Smith, E. (2006). Applying holistic principles in management development, Journal of Management Development, Vol. 25 Issue: 4, pp.368385

Slaughter, R., (2012). Welcome to the anthropocene, Futures, 44, Special Issue: University Learning, pp.119-126

Sturdy, A, Brocklehurst, M. Winstanley, D, Littlejohns, M. (2006). Management as a (Self) Confidence Trick: Management Ideas, Education and Identity Work Organization; 13, 6, 841

Sugarman, L., (2001). Life-span Development: Frameworks, Accounts and Strategies. New York, Psychology Press.

Tsoukas, H. (2011). How should we understand tacit knowledge? A phenomenological view. in M. Easterby-Smith and M. Lyles (eds), Handbook of Organizational Learning and Knowledge Management, $2^{\text {nd }}$ edition, pp 435 - 476, Wiley van Manen, M., (1990). Researching Lived Experience: Human Science for an Action Sensitive Pedagogy, State University of New York Press; 2nd edition 
"Reflection is embedded in my brain forever now!": Personal Development as a core module on

Waddock, S, \& Lozana, J (2013). Developing More Holistic Management Education: Lessons Learned From Two Programs, Academy Of Management Learning \& Education, 12, 2, pp. 265-284

Weick, K, Sutcliffe, K, \& Obstfeld, D., (2005). Organizing and the Process of Sensemaking, Organization Science, 16, 4, pp. 409-421.

Yang, C., Goralski, M. (2016). Mindfulness and its Pedagogical Application in Business Education, Journal of International Business Disciplines, vol 11, no. 2, pp. 15-28

Yanow, D, \& Tsoukas, H. (2009). What is Reflection-In-Action? A Phenomenological Account, Journal Of Management Studies, 46, 8, pp. 1339-1364

Waters, C. N., Zalasiewicz, J. A., Williams, M. Ellis, M. A., Snelling, A. M., (eds) (2014). A Stratigraphical Basis for the Anthropocene, GSL Special Publications

Wagenheim, G, (2014) Professional artistry revealed: business professors' use of reflection in their teaching, Reflective Practice, 15:6, 836-850

Whittington, J. (2016). Systemic Coaching and Constellations, $2^{\text {nd }}$ edition. Kogan Page 